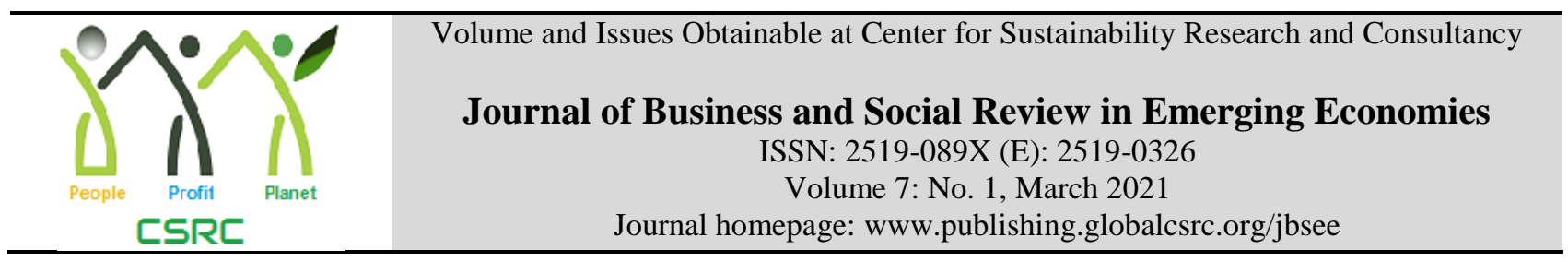

\title{
Do Female Head Teachers in Punjab, Pakistan, Receive Sufficient Family Support to Balance Domestic and Professional Responsibilities?
}

*Fayyaz Ahmad Ranjha, Education Officer, School of Education Department, Punjab, Pakistan Chairperson/Assistant Professor, Department of Special Education, (DOE)

Shaheen Pasha, University of Education, Lahore, Pakistan

Shakeela Shah, Dept. of Curriculum Development \& Instructions, Faculty of Education

University of Sindh, Jamshoro, Pakistan

*Corresponding author's email address: fiazahmad73@yahoo.com

ARTICLE DETAILS ABSTRACT

\section{History}

Revised format: Feb 2021

Available Online: Mar 2021

Keywords
Female Head Teachers,
Family Support, Dual
Responsibility.

JEL Classification:

M11, M12

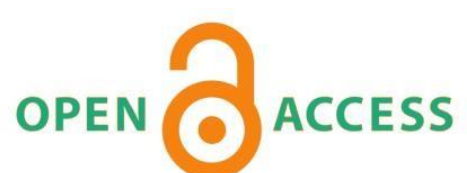

Working women are contributing on both fronts, both in the domestic setting and in the workplace. These double duties have made their lifestyle and routine hectic. To become successful in the workplace and in the home they need social support from their family. The main objective of this study was to identify the behavior and support that female head teachers receive from their husbands and children to help manage their work life balance efficiently. This study is descriptive in nature. Female head teachers of primary public schools in the district of Lahore were the population of this study. A total of 30 head teachers, in addition to their husbands and one child each, were selected from public primary schools through a convenient sampling technique. Three questionnaires were developed using a five-point likert scale as a research tool. The questionnaires consisted of three sections, the first for the female head teachers, the second for their husbands and third for their children to determine the level of support received by the woman and their feelings towards this. Results of the study showed that government primary school head teachers were not satisfied with the support they were receiving from their husbands, but they are satisfied with their child's support. To help manage their time efficiently in both work and personal life, women require more support from their husbands to help care for their children and maintain the household.

\section{(C) 2021 The authors, under a Creative Commons Attribution-} NonCommercial 4.0

Recommended citation: Ranjha, F. A., Pasha, S. \& Shah, S. (2021). Do Female Head Teachers in Punjab, Pakistan, Receive Sufficient Family Support to Balance Domestic and Professional Responsibilities. Journal of Business and Social Review in Emerging Economies, 7(1), 167-174.

\section{Introduction}

Females comprise almost half of any society and play an important role in all aspects of life, but their 
services are often less acknowledged than that of their male counterparts. Appreciation for their capabilities is often lacking and women can be required to become stronger characters in order to stand out in their field of work above men. Women hold up half the sky, but the world is ruled by men (Ballenger, 2010). In order for society to progress, women must be considered equal to men in both formal and informal fields and should face less challenges in the workplace. Although women played an important role in the industrial area, their helping hand was not accepted. (Allen \& Sachs, 2012). This trend is changing swiftly and now the work of the women is recognised to a greater extent and they have gained more respect in the workplace.

Family members are a major source of social support for females who are in work and research suggests social support has a positive effect on the mental health and overall well being of working women. (Goh, Ilies, \& Wilson, 2015; Wadsworth \& Owens, 2007). Despite this, family support has not been widely discussed and researched in relation to jobs. Family support has two components; contributory support, which refers to palpable help from the partner in the form of participation in home maintenance and child care whilst the other component refers to the emotional support provided by the family, which refers to information, advice, affirmation of affection, and concern for the receiver's welfare displayed by the partner (Parasuraman, Purohit, Godshalk, \& Beutell, 1996).

Women play a vital role in a country's development and they hold roles in almost all aspects of life. The department of education is one of the best fields to accommodate women in the workplace and they often excel in this field. In all levels of the education system, from elementary through to middle and high school, females can be seen holding the highest-ranking role of the head teacher. The responsibility of the head teacher is to manage all matters inside the school and deal with any problem that occurs, whether it is a problem with a teacher, administrator or with a student. The purpose of this study was to perceive which aspects of support a family gives to a female head teacher to help her perform these duties while continuing to maintain the home.

\section{Objectives of the Study}

The objectives of the study were to

1. Identify the behavior of the husbands and children towards female head teachers and their job.

2. Identify the support that female head teachers receive from their husbands and children to help manage their jobs efficiently.

3. Determine the income contribution of head teachers to their families.

4. Identify the effect of having a job on the wellbeing of female head teachers.

\section{Literature Review}

Female head teachers are facing both internal and external challenges. The external challenges include the increasing accountability demands by the government, political interference, budget restrictions, parental pressure, general apathy of the public, rapid population growth, explosion of knowledge and information technology and challenging competition. (Middlehurst, 2004). The internal challenges include the rising militancy of the teachers and restlessness among the students. These challenges distract the working women and they affect their role which can be seen in poor academic standards in the primary schools of Pakistan. One must consider these problems in order to make better advancement. (Helgoy,\& Homme, 2007). According to Bruner (1998) there are many factors that influence the working life of female head teachers (Cubillo, \& Brown, 2003). Tamboukou (2010) indicated that women who were able to maintain a balance between family and work lives were successful in their careers.

Most families in Pakistan no longer fit the traditional stereotype in which fathers are breadwinners and mothers stay home to care for the children and maintain the household responsibilities such as cooking and cleaning. (Rehman, \& Azam, 2012) Working mothers still act as a main support in the family and children are still taken care of by them. Although they can balance their work and home lives, their first 
priority is their family. In Pakistan the majority of married female head teachers reported role conflict between work and family. They practiced compartmentalization as a way to separate work and home responsibilities. (Rehman, \& Azam, 2012) A research conducted by American Academy of Pediatrics, (1999) identified the positive and negative effects on the children of working mothers. Negative impacts included: "the more hours a mother works the lower the child's language development and academic achievement". According to this research the improvement in living standards by working mothers offset any negatives (Pamela, 2008).

In Pakistan, working women are expected to perform more tasks within the home alongside their professional commitments compared to men, e.g. women were found to complete laundry duties and take responsibility for meal preparation and shopping. Working women can also face stress due to the sickness of children that need to be cared for and necessary household chores. (Khan,1999; Ashraf \& Farah, 2007; Malik, Saif, Khan, \& Hussain, 2010). Marcinkus et al. (2006) found that the women generally received more personal social support than work based social support from maximum available sources. Personal social support was also found to be associated with job satisfaction and organizational commitment. Work related social support comes from the organizational members, such as peers and supervisors, where an employee works, whereas personal social support comes from spouse, parents, children, extended family or friends. Brough and Pears (2004) defines social support as, being bifurcated into two facets such as organizational support and family related support. For this study, the social support (work based and family based) was considered as one variable.

\section{Methodology of Study}

The study is descriptive in nature. Female head teachers of primary public schools of the district of Lahore were the population of the study. A total of 30 head teachers (their husband and one child per family) were selected from public primary schools through a convenient sampling technique. This study was based on family issues, therefore the participation of the husbands and children was essential to the study.

\section{Instrumentation}

Three questionnaires were developed on a five-point scale (strongly agree, agree, neutral, disagree, strongly disagree) as a research tool. Data was collected from female head teachers and their husbands and form one child from every family with the help of a five-point rating scale. The researchers personally visited the selected schools for data collection. The questionnaire consisted of three sections, one for female head teachers, the second for their husbands and third for the child, to find out whether a woman has support from her family or not. The questionnaire covered information related to five aspects:

- Interfamily relationships

- Satisfaction with the job of head teachers from family

- Help given to female head teachers for household chores from the family

- Social acceptance

- Economic conditions

The questionnaires were printed in both English and Urdu languages so that the participants could easily understand the statements. This study was carried out on 30 public primary girls' schools only, located in the Lahore district. The data was analyzed through SPSS and was interpreted to explain the problem.

\section{Data Collection}

Data from head teachers was collected by the researchers themselves. Researchers faced different difficulties during the data collection process e.g.

- Gaining access to thirty different public primary girls' schools located in the Lahore district was a difficulty as some schools were located in rural areas where a suitable transport facility was not easily available. 
- Some head teachers were not cooperative.

- Researchers needed to visit the schools several times to collect questionnaires.

- Some head teachers were not willing to fill in the questionnaires as it was against their school policy.

- Access of researchers to head teachers' family members was a difficult task.

\section{Data Analysis}

The collected data was tabulated and analyzed using SPSS (Statistical Package for Social Studies) software which highlighted the support provided by the husbands to married female head teachers and also gave insight into the support which was given by the children to their mothers.

Table 1. Interpretation of scale as used in analysis

\begin{tabular}{lll}
\hline Scale & Mean Range & Verbal Interpretation \\
\hline 5 & $4.51-5.00$ & Strongly Agree \\
4 & $3.51-5.00$ & Agree \\
3 & $2.51-3.50$ & Moderate agree \\
2 & $1.51-2.50$ & slightly agree (Disagree) \\
1 & $1.00-1.50$ & Disagree (Strongly disagree) \\
\hline
\end{tabular}

Table 2. Distribution of Participants

\begin{tabular}{ccc}
\hline \multicolumn{2}{c}{ Distribution of the head teachers with respect to experience(N=30) } & \\
\hline Category & Frequency & Percentage \\
\hline$\leq 5$ & 09 & $30 \%$ \\
$10-15$ & 08 & $26.2 \%$ \\
$\geq 16$ & 13 & $43.3 \%$ \\
\hline Distribution of the head teachers with respect to experience(N=30) & \\
\hline$\leq 30$ & 13 & $43.3 \%$ \\
$31-40$ & 10 & $33.3 \%$ \\
$41-50$ & 5 & $16.6 \%$ \\
$\geq 50$ & 2 & $6.6 \%$ \\
Male & 15 & $50 \%$ \\
Female & 15 & $50 \%$ \\
\hline
\end{tabular}

Table 3. Children's point of views about the time management of their mothers (head teachers) for their different activities

\begin{tabular}{lccccc}
\hline \multicolumn{1}{c}{ Statements } & Mean & Median & SD & Min & Max \\
\hline Time management of mothers for their children & 4.07 & 3.03 & .63 & 2.00 & 5.00 \\
Give time for outing to their children & 3.03 & 3.00 & .73 & 1.71 & 4.43 \\
Taking interest in studies of their children & 3.86 & 0.72 & .49 & 2.00 & 4.80 \\
Taking interest in the personal work of their children & 3.35 & 1.71 & .63 & 1.75 & 4.75 \\
Mothers give pick and drop for school to children & 3.95 & 4.01 & .76 & 1.33 & 5.00 \\
Taking interest in their children's problems & 3.39 & 0.72 & .95 & 1.00 & 5.00 \\
Taking children brought up responsibility & 3.43 & 1.00 & .84 & 1.00 & 5.00 \\
Mothers available for shopping & 4.07 & 3.03 & .63 & 2.00 & 5.00 \\
Children have interest in their mothers' schools & 4.07 & 3.03 & .49 & 2.00 & 4.80 \\
\hline
\end{tabular}

Table 3 shows the opinion of the children about the time management of their mothers at home. Most children responded positively about the time management of the mother at home (mean=4.07, close to agree option), children slightly agreed that the mother gave them time for outings (mean=3.03, close to undecided option), children substantially responded that the mother took an interest in their studies (mean=3.86, close to agree option). Most children responded that the mother took an interest in their personal work (mean $=3.35$, close to undecided option), children substantially responded that the mother performed pick up and drop off duties for school (mean=3.95, close to agree option), most children responded that the mother took an interest in their personal problems (mean=3.39, close to undecided option), children substantially responded that the mother took responsibility for their upbringing (mean=3.43, close to agree option). Children substantially responded that the mother was available for 
shopping (mean=4.07, close to agree option), most children recorded an interest in the school of the mother (mean=4.07, close to agree option).

Table 4. Husbands' attitude about the job their wives (head teachers)

\begin{tabular}{lccccc}
\hline \multicolumn{1}{c}{ Statements } & Mean & Median & SD & Min & Max \\
\hline Sharing /handling domestic chores with wives & 3.07 & 1.03 & .63 & 2.00 & 5.00 \\
Satisfied with time balancing of wife between home and school & 3.03 & 3.00 & .73 & 1.71 & 4.43 \\
Husband's view about mutual relationship & 3.86 & 0.72 & .49 & 2.00 & 4.80 \\
Understanding of wife's professional responsibilities & 3.35 & 1.71 & .63 & 1.75 & 4.75 \\
Husband's behavior in different situations & 3.95 & 4.01 & .76 & 1.33 & 5.00 \\
Sharing income of wife & 3.85 & 0.72 & .95 & 1.25 & 4.75 \\
\hline
\end{tabular}

Table 4 shows the opinion of the husbands about the job of their wives. Most husbands did not share the domestic chores with the wife (mean $=3.07$, close the undecided option). Husbands were not satisfied with the time balancing of the wife between home and school (mean=3.03, close to undecided option). Husbands responded substantially that they were not satisfied with the mutual relationship with their wife (mean=3.86, close to agree option). Most husbands had a moderate level of understanding of the wife's professional responsibilities (mean $=3.35$, close to undecided option). Most husbands substantially responded that they had positive behavior in different situations with their wife (mean=3.95, close to agree option).

Table 5. Head teachers's point of views about managing domestic affairs with job responsibilities

\begin{tabular}{lccccc}
\hline \multicolumn{1}{c}{ Statements } & Mean & Median & SD & Min & Max \\
\hline Doing job by their choice & 4.07 & 3.03 & .63 & 2.00 & 5.00 \\
Facing difficulty for looking after home & 2.03 & 3.00 & .73 & 1.71 & 4.43 \\
Receiving more importance among people because of job & 3.86 & 0.72 & .49 & 2.00 & 4.80 \\
Financially independent & 2.35 & 1.71 & .63 & 1.75 & 4.75 \\
Satisfaction with current economic situation of home & 2.65 & 0.72 & .49 & 2.00 & 4.80 \\
Spending time cooking & 4.00 & 4.01 & .76 & 1.33 & 5.00 \\
Remained stressed for household chores during school & 4.39 & 0.72 & .95 & 1.00 & 5.00 \\
Favorable and helpful family members & 2.00 & 3.00 & .73 & 1.71 & 4.43 \\
Handling alone children's educational and other matters & 3.75 & 0.72 & .49 & 2.00 & 4.80 \\
\hline
\end{tabular}

Table 5 shows the opinion of female head teachers about their different duties at home. Most substantially responded that they are doing their job by choice (mean=4.07, close to agree option). Most responded negatively that they faced difficulty for looking after home (mean=2.03, close to disagree option). Most female heads responded that they received more importance among people because of their job (mean=3.86, close to agree option). A low level of female heads were financially independent (mean $=2.35$, close to moderate agree option). Female heads were slightly satisfied with the current economic situation of the home (mean $=2.65$, close to moderate agree option) Most female heads substantially responded that they spent time cooking (mean=4.00, close to the agree option). Female heads responded substantially that they remained stressed about household chores during school (mean $=4.39$, close to the agree option). Female heads responded negatively that they have favorable and helpful family members (mean=2.69, close to moderate agree option). Mostly female heads felt they had to handle the child's educational and other matters alone (mean=3.75, close to undecided option).

Table 6. Head teachers's point of views about managing time for their children affairs

\begin{tabular}{|c|c|c|c|c|c|}
\hline Statements & Mean & Median & SD & Min & Max \\
\hline Children's satisfaction of time management of their mothers for them & 3.65 & 3.03 & .63 & 2.00 & 5.00 \\
\hline Head teachers find time for outing & 3.03 & 3.00 & .73 & 1.71 & 4.43 \\
\hline Mothers' interest in their children's studies & 4.86 & 0.72 & .49 & 2.00 & 4.80 \\
\hline Find time for children's personal work & 3.35 & 1.71 & 63 & 1.75 & 4.75 \\
\hline Manage pick and drop for children to school & 3.95 & 4.01 & .76 & 1.33 & 5.00 \\
\hline Manage time to solve children's problems & 3.39 & 0.72 & .95 & 1.00 & 5.00 \\
\hline Fulfilling the brought up responsibility of children & 3.25 & 0.72 & .49 & 2.00 & 4.80 \\
\hline Mothers' availability to children for shopping & 2.35 & 3.00 & .73 & 1.71 & 4.43 \\
\hline
\end{tabular}




\begin{tabular}{llllll}
\hline Children having interest in their mothers' schools & 4.00 & 0.72 & .49 & 2.00 & 4.80 \\
\hline
\end{tabular}

Table 6 shows the head teachers' point of views about managing time for their children's affairs. Mostly female heads felt they had a moderate level of satisfaction for their time management from their children (mean=3.65, close to undecided option). Most female heads felt they had a moderate level of time for outings (mean=3.03, close to undecided option). Most female heads felt they had a high level of interest in their children's studies (mean=4.68, close to decided option). Most female heads felt they had a moderate level of time for their children's personal work (mean=3.35, close to undecided option). Female heads felt they had a high level of time to manage the pick up and drop off responsibilities for their children to attend school (mean=3.95, close to decided option). Most female heads felt they had a moderate level of time to manage and solve their children's problems (mean $=3.39$, close to undecided option). Female heads felt they had a low level of time to fulfill the responsibility of bringing up their children (mean $=2.35$, close to moderate agree option). Female heads felt they had a low level of time for shopping (mean=3.25, close to undecided option). Female heads felt their children had a high level of interest in their mother's school (mean $=4.00$, close to decided option).

\section{Findings}

Results of the study showed that government primary school head teachers are not satisfied with the support which they were receiving from their husbands but they are satisfied with their children's support. It is evident from the data that the children of female heads are satisfied with the time management of their mothers at home and head teachers that are mothers give sufficient time for outings with their children. Children said that the mothers are taking interest in their studies, spare time for shopping and manage the pick-up and drop off responsibilities for the children to attend school. Most children are taking interest in their mother's school. However, children are not satisfied that their mothers are not taking interest in their personal work. The data reveals that husbands of female heads don't share the domestic chores with their wives. Husbands are not satisfied with the time balance of their wives between home and school. Husbands are not satisfied with mutual relationships with their wives. Most husbands claim that they have an understanding of their wife's professional responsibilities and they have positive behavior in different situations with their wives.

Female head teachers are doing the job by their own choice but they have to perform plenty of additional duties at home compared to men. Heads are receiving more importance among people because of their job but they are not financially independent. They are not satisfied with the current economic situation of their home and they have to spend time cooking. They remained stressed about household chores during school hours. They claim that their children are not satisfied with their time management. They take interest in their children's studies and manage the pick-up and drop off responsibilities for children to attend school. Female heads are not able to fulfill the responsibility of bringing up their children. They can't manage time for their children's personal work e.g. shopping.

\section{Conclusion}

Based on this study of findings, it can be concluded that head teachers need support of their family members to perform their duties efficiently. They are doing their job because of economic need. It is also concluded that the majority of the female head teachers do not receive satisfactory support from their husbands to do their job. The friends and relatives of head teachers are in favour of their school head teacher job and they are given more importance because of it. Generally, catering for the home affairs is still regarded as the essential part of the role of a Pakistani woman. In the competitive environment, they are expected to combine their home responsibilities with their working life. Women generally receive more social support from work and family, whereas the researchers' findings suggest that the female head teachers are receiving acceptance from other family members and society. It is concluded that head teachers have to deal with both domestic and professional responsibilities at the same time and they need to manage their time carefully to not receive complaints from their family. Results of this study are presenting the picture of the support of husbands to their wives and of children to their mothers that they support in day to day household matters to some extent. It is concluded that 
husbands are accepting the efforts of their wives in enhancing the income of their family and they are standing shoulder to shoulder with them.

\section{Recommendations}

The following recommendations were made on the basis of the study.

- Head teachers need support from family members to achieve their professional goals as well as household tasks with full peace of mind.

- Husbands should maintain a friendly relationship with their wives who are working outside of the house to earn, so working women can receive relief from their husbands' strict behavior and share all kinds of problems with them without any fear.

- The polite, friendly and supportive behavior of family members strengthens the power of the head teachers to stand firm in any kind of difficult situations.

- To bring up the morale of the head teachers to cope successfully with both domestic and professional tasks, husbands should guide them in hectic situations of their profession and keep their attitude polite and pleasant in domestic affairs.

- To manage their time for their family in an easy way, it is the husband's responsibility that they step forward and fulfill their children's needs.

- Children of the head teachers should be a helping hand to their mothers' by doing their own work to reduce their mothers' burden.

\section{References}

Rehman, S., \& Azam R. M. (2012). Gender and work-life balance: a phenomenological study of women entrepreneurs in Pakistan. Journal of small business and enterprise development, 19(2), 209-228.

Pamela C. (2008). School readiness. Pediatrics, 121(4) DOI: https://doi.org/10.1542/peds.2008-0079

Ballenger, J. (2010). Women's Access to Higher Education Leadership: Cultural and Structural Barriers. In Forum on Public Policy Online (Vol. 2010, No. 5). Oxford Round Table. 406 West Florida Avenue, Urbana, IL 61801.

Allen, P., \& Sachs, C. (2012). Women and food chains: The gendered politics of food. Taking food public: Redefining foodways in a changing world, 23-40.

Goh, Z., Ilies, R., \& Wilson, K. S. (2015). Supportive supervisors improve employees' daily lives: The role supervisors play in the impact of daily workload on life satisfaction via work-family conflict. Journal of Vocational Behavior, 89, 65-73.

Wadsworth, L. L., \& Owens, B. P. (2007). The effects of social support on work-family enhancement and work-family conflict in the public sector. Public Administration Review, 67(1), 75-87.

Parasuraman, S., Purohit, Y. S., Godshalk, V. M., \& Beutell, N. J. (1996). Work and family variables, entrepreneurial career success, and psychological well-being. Journal of vocational behavior, 48(3), 275-300.

Middlehurst, R. (2004). Changing internal governance: A discussion of leadership roles and management structures in UK universities. Higher Education Quarterly, 58(4), 258279.

Fantilli, R. D., \& McDougall, D. E. (2009). A study of novice teachers: Challenges and supports in the first years. Teaching and teacher education, 25(6), 814-825.

Helgoy, I., \& Homme, A. (2007). Towards a new professionalism in school? A comparative study of teacher autonomy in Norway and Sweden. European educational research journal, 6(3), 232-249.

Cubillo, L., \& Brown, M. (2003). Women into educational leadership and management: international differences?. Journal of educational Administration, 41(3), 278-291.

Tamboukou, M. (2010). Relational narratives: Auto/biography and the portrait. In Women's Studies International Forum (Vol. 33, No. 3, pp. 170-179). Pergamon. 
Grogan, M., \& Shakeshaft, C. (2010). Women and educational leadership (Vol. 10). John Wiley \& Sons.

Khan, A. (1999). Mobility of women and access to health and family planning services in Pakistan. Reproductive health matters, 7(14), 39-48.

Ashraf, D., \& Farah, I. (2007). Education and women's empowerment: Re-examining the relationship. Education, gender and empowerment: Perspectives from South Asia, 15.

Malik, M. I., Saif, M. I., Khan, N., \& Hussain, S. (2010). Balancing work and family through social support among working women in Pakistan. African Journal of Business Management, 4(13), 2864-2870.

Marcinkus, W. (2007), The Relationship of Social Support to the Work - Family Balance and Work Outcomes of midlife Women. Women Manage. Rev., 22(2): 86-111.

Brough P, Pears J (2004). Evaluating the Influence of the Type of Social Support on Job Satisfaction and Work Related Psychological Wellbeing. Int. J. Organ. Behav., 8(2): 472-485 